\title{
RELASI MAKNA ANTONIM VERBA \\ BAHASA DAYAK KANAYATN KALIMANTAN BARAT
}

\section{The Relationship Between the Meaning of Antonyms Verbs in the Dayak Kanayatn Language of West Kalimantan}

\author{
Saptiana Sulastri \\ Program Studi Pendidikan Bahasa dan Sastra Indonesia, IKIP PGRI Pontianak \\ Jalan Ampera No. 88 Pontianak \\ Pos-el:saptianasulastri292@gmail.com
}

\begin{abstract}
Abstrak
Penelitian ini bertujuan untuk mendeskripsikan relasi makna antonim verba dalam bahasa Dayak Kanayatn Kalimantan Barat. Kajian tersebut dibatasi hanya pada antonim mutlak, antonim hubungan, dan antonim majemuk. Metode yang digunakan adalah metode deskriptif dengan bentuk penelitian kualitatif. Data penelitian berbentuk tuturan berupa kata-kata dan kalimat bahasa Dayak Kanayatn yang mengandung relasi makna antonim, serta sumber datanya adalah tiga orang masyarakat sebagai instrument kunci utama dan dibantu oleh masyarakat. Berdasarkan analisis data, hasil penelitian ditemukan (a) antonim mutlak seperti: kata yeak (menangis) dengan kata galak (tertawa), kata makatn (makan) dengan kata nocok (minum), kata tidur (tidur) dengan kata lumpat (bangun). (b) Antonim majemuk seperti: antonim hubungan seperti: kata nual (menjual) dengan kata mali (membeli), kata maju (maju) dengan kata mundur (mundur), kata turutn (turun) dengan kata naik (naik), kata pulaky (pulang) dengan kata ampus (pergi). (c) antonim majemuk seperti: kata badiri (berdiri) dengan kata duduk (duduk) dan guriky (berbaring), tidur (tidur).
\end{abstract}

Kata-kata Kunci: Relasi Makna, Antonim, Verba

\begin{abstract}
This study aims to describe the relationship between the meaning of antonyms verbs in the Dayak Kanayatn language of West Kalimantan. The study is limited to absolute antonyms, relationship antonyms, and compound antonyms. The method used is descriptive method with a form of qualitative research. The research data in the form of speech in the form of words and sentences in the Dayak Kanayatn language which contains the relation of antonym meaning, and the source of the data are three people as the main key instrument and assisted by the community. Based on data analysis, the results of the study found (a) absolute antonyms such as: the word yeak (crying) with the word fierce (laughing), the word makatn (eating) with the word Beat (drink), the word sleep (sleep) with the word lumpat (wake). (b) Compound Antonyms such as: antonym relations such as: the word nual (sell) with the word mali (buy), the word forward (forward) with the word backward (backward), co-word (down) with the word up (up), word pulaky (go home) with the word ampus (go). (c) compound antonyms such as: bwak (standing) with words sitting (sitting) and guriky (lying down), sleeping (sleeping).
\end{abstract}

Keywords: Relation of Meaning, Antonym, Verb 


\section{PENDAHULUAN}

Bahasa merupakan sarana komunikasi yang sangat penting keberadaannya bagi masyarakat. Bahasa digunakan untuk mengungkapkan ide, pikiran, dan perasaan kepada orang lain, sehingga akan terjalin interaksi antara masyarakat, tanpa bahasa komunikasi tidak akan terjalin dengan baik. Menurut Anwar (2003) mengemukakan bahwa "bahasa adalah sistem lambang bunyi yang arbitrer, yang dipergunakan oleh para anggota suatu masyarakat untuk berkerja sama, berinteraksi, dan mengidentifikasikan diri" (hlm. 71).

Kalimantan Barat khususnya Kabupaten Landak, terdiri dari banyak bahasa di antaranya bahasa Dayak, bahasa Melayu, bahasa Madura, bahasa Cina dan lain-lain. Namun peneliti lebih tertarik pada bahasa Dayak, khususnya pada bahasa Dayak Kanayatn Kecamatan Sompak dialek Ahe Kabupaten Landak.

Bahasa daerah adalah suatu bahasa yang dituturkan disuatu wilayah dalam sebuah Negara kebangsaan pada suatu daerah kecil. Bahasa Dayak Kanayatn adalah sebuah bahasa yang dipertuturkan di wilayah Kabupaten Landak, Kalimantan Barat, Indonesia khususnya di Dusun Simpang Tiga Desa Tapakng Kecamatan Sompak. Bahasa Dayak Kanayatn Kecamatan Sompak dialek Ahe Kabupaten Landak merupakan satu diantara bahasa daerah yang ada di Kalimantan Barat yang hingga saat ini masih digunakan oleh masyarakat setempat.

Alasan peneliti memilih bahasa Dayak Kanayatn sebagai objek penelitian yaitu 151 | pertama, karena bahasa Dayak Kanayatn sebagai lambang identitas kebanggaan masyarakat Dayak Kanayatn Dusun Simpang Tiga, Desa Tapakng, Kecamatan Sompak, Kabupaten Landak. Kedua, peneliti ingin mendokumentasikan keaslian bahasa Dayak Kanayatn kepada masyarakat luas, untuk menjaga kelestarian bahasa Dayak Kanayatn. Ketiga, karena bahasa Dayak Kanayatn mudah sekali berubah seiring dengan perkembangan bahasa itu sendiri dan pengaruh bahasa Indonesia maupun bahasa daerah lainnya.

Pemilihan relasi makna dalam penelitian ini yaitu pertama, adanya hubungan kemaknaan antara sebuah kata atau satuan bahasa lainnya. Kedua, karena adanya hubungan sinonim, antonim, dan polisemi antara bahasa yang dituturkan oleh warga/masyarakat dan informan. Ketiga, peneliti ingin mendeskripsikan adanya makna kata yang saling berhubungan.

Penelitian tentang relasi makna kata sudah pernah dilakukan oleh mahasiswa IKIP PGRI Pontianak yaitu Herkulanus Setar (2015). Setar meneliti relasi makna kata dengan judul "Relasi Makna Kata dalam Bahasa Dayak Bekidoh Kecamatan Jangkang" setar dalam penelitiannya meneliti tentang relasi makna kata sinonim, kata antonim, kata homonim, kata hiponim, dan yang terakhir kata polisemi. Adapun hasil penelitan setar terdapat lima puluh satu pasang sinonim yaitu sinonim total dan komplit, sinonim tidak total tetapi komplit, sinonim total tetapi tidak komplit, dan sinonim tidak total dan tidak komplit. Terdapat empat puluh delapan pasang antonim yang terbagi 
menjadi lima jenis antonim yaitu antonim mutlak, antonim kutub, antonim hubungan, antonim hierarkial dan antonim majemuk, dua belas homonim, sepuluh hiponim, dan lima belas polisemi.

Berdasarkan berbagai alasan yang telah dikemukakan, maka penelitian ini dianggap sangat perlu dilakukan, karena dapat mengangkat khasanah kebahasaan lokal kalimantan barat. adapun permasalahan yang diangkat dari penelitian ini adalah mengenai Relasi Makna Antonim Verba Bahasa Dayak Kanayatn Kalimantan Barat.

\section{LANDASAN TEORI}

Kajian semantik adalah suatu pengkajian cabang dari linguistik yang memfokuskan kajiannya pada suatu makna bahasa. Selain itu kajian semantik juga dapat diartikan sebagai kajian studi tentang makna yang digunakan untuk memahami makna kata yang dituturkan oleh masyarakat penutur.

Semantik adalah cabang ilmu linguistik yang mempelajari arti/makna yang terkandung pada suatu bahasa, semantik dapat pula diartikan sebagai ilmu yang menjadikan makna sebagai objek kajiannya. Menurut Anwar (2003) mengemukakan bahwa "semantik merupakan ilmu arti kata atau pengetahuan mengenai selukbeluk dan pergeseran arti kata-kata" (hlm. 421). Sementara itu, Menurut Tarigan (2011) "semantik adalah telaah makna. Semantik menelaah lambang-lambang atau tanda-tanda yang menyatakan makna, hubungan makna yang satu dengan yang lain, dan pengaruhnya terhadap 152 manusia serta masyarakat" (hlm. 147). Sedangkan menurut Karim, dkk. (2013) mengemukakan bahwa "Semantik digunakan para pakar bahasa untuk menyebut bagian ilmu bahasa yang mempelajari makna atau arti dalam bahasa dan menjadi salah satu dari tiga tataran analisis bahasa, yaitu fonologi, gramatika/tata bahasa, dan semantik". (hlm. 1)

Relasi dapat diartikan sebagai hubungan. Hubungan yang dimaksud adalah hubungan antara makna kata yang satu dengan kata yang lainnya. Relasi adalah aturan yang menghubungkan setiap kata yang satu dengan kata yang lainnya. Menurut Anwar (2003) "relasi adalah hubungan, perhubungan atau pertalian" (hlm. 360).

Makna adalah arti atau maksud yang tersimpul dari suatu kata itu sendiri, jadi makna dengan bendanya sangat bertautan dan saling menyatu. Menurut Bolinger (Aminudin, 2011) "makna ialah hubungan antara bahasa dengan dunia luar yang telah disepakati bersama oleh para pemakai bahasa sehingga dapat saling dimengerti” (hlm. 52-53). Sementara itu, Menurut Karim, dkk. (2013) mengemukakan bahwa "makna merupakan salah satu persoalan bahasa dalam kehidupan manusia yang sangat erat" (hlm. 10). Sedangkan menurut Djajasudarma (1999) "pengertian makna di dalam semantik. Makna adalah pertautan yang ada di antara unsur-unsur bahasa itu sendiri (terutama kata-kata)" (hlm. 5).

Antonim adalah hubungan semantik antara dua buah satuan ujaran yang maknanya menyatakan kebalikan atau pertentangan. 
Menurut karim, dkk. (2013) “antonim adalah hubungan semantik antara dua buah satuan ujaran yang maknanya menyatakan kebalikan, pertentangan, atau kontras antara yang satu dengan yang lain. Hubungan antara dua satuan ujaran yang berantonim juga bersifat dua arah" (hlm. 43). Sementara itu, menurut Chaer (2014) "antonim atau antonimi adalah hubungan semantik antara dua buah satuan ujaran yang maknanya menyatakan kebalikan, pertentangan, atau kontras antara yang satu dengan yang lain" (hlm. 299). Sedangkan menurut Tarigan (2009) "kata antonim terdiri atas anti atau ant yang berarti 'lawan' ditambah akar kata onim atau onuma yang berarti 'nama', yaitu kata yang mengandung makna yang berkebalikan atau berlawanan dengan kata yang lain" (hlm. 30). Sejalan dengan pendapat Wijana (2015) mengemukakan bahwa "antonim adalah perlawanan makna. Misalnya, kata hidup dan mati, tua dan muda, besar dan kecil, dan sebagainya" (hlm. 55).

\section{Menurut Alwasilah}

mengemukakan bahwa "antonim adalah beberapa pasangan kata mempunyai arti yang berlawanan. Relasi ini disebut antonimy, dan kata-kata yang berlawanan ini disebut antonimy (anatonymy)" (hlm. 172). Sementara itu, Menurut Anwar (2003) mengemukakan bahwa "antonim adalah kata yang berlawanan makna dengan kata lain" (hlm. 52). Sedangkan menurut Rohmadi (2011) mengemukakan bahwa "antonim adalah perlawanan makna. Kata lakilaki berantonim dengan perempuan, mati berantonim dengan hidup, jauh berantonim 153 | dengan dekat, adik berantonim dengan kakak dan sebagainya" (hlm. 25). Menurut Oktaviani (2009) mengemukakan bahwa "antonim adalah dua bentuk kata yang mempunyai hubungan makna yang berlawanan (hlm. 39). Sejalan dengan pendapat Chaer (2009) mengemukakan bahwa "antonim dapat dibedakan menjadi 5 antara lain: (1). Oposisi mutlak, (2). Oposisi kutub, (3). Oposisi hubungan, (4). Oposisi hierarkial, dan (5). Oposisi majemuk. Pada penelitian ini peneliti memfokuskan antonim yaitu: Oposisi mutlak, Oposisi hubungan, dan Oposisi majemuk (hlm. 88).

Contohnya: ayak (besar) dan enek (kecil), ampus (pergi) dan pulakng (pulang), galak (tertawa) dan ngeak (menangis), makatn (makan) dan nocok (minum), muka (membuka) nutup (menutup) dan lain sebagainya.

Berdasarkan definisi di atas dapat disimpulkan bahwa antonim merupakan hubungan semantik antara dua buah kata yang maknanya menyatakan pertentangan atau kebalikan. Atau lebih sederhananya antonim adalah satu kata yang

Verba atau kata kerja merupakan kelas kata yang menyatakan suatu tindakan, keadaan, atau pengertian dinamis lainnya. Jenis kata ini umumnya menjadi predikat dalam suatu frasa atau kalimat. Menurut Finoza (2009) "kata kerja atau verba adalah kata yang menyatakan perbuatan atau tindakan, proses, dan keadaan yang bukan merupakan sifat dan kualitas. Kata kerja pada umumnya berfungsi sebagai predikat dalam kalimat" (hlm. 83). Sementara itu, Menurut Wahyudi, dkk. (2012) mengemukakan 
bahwa "kata kerja (verba) ialah semua kata yang menyatakan perbuatan atau laku" (hlm. 146).

Menurut Solahudin (2009) "verba atau kata kerja ialah kata yang menunjukkan perbuatan yang dilakukan seseorang atau sesuatu, atau menunjukan keadaan” (hlm. 75). Sejalan dengan pendapat Mulae (2005) mengemukakan bahwa "verba didefinisikan adalah kata-kata yang menggambarkan aksi dan keadaan. Dalam hal ini kata-kata yang menyatakan perbuatan atau tindakan" (hlm. 11). Sementara itu, Menurut Melia (2016) "verba memiliki fungsi utama sebagai predikat atau inti predikat dalam kalimat" (hlm. 63). Sedangkan menurut Anwar (2003) "verba adalah kata kerja atau kata yang menggambarkan proses, perbuatan atau keadaan" (hlm. 587).

Berdasarkan definisi di atas dapat disimpulkan bahwa verba atau kata kerja merupakan kelas kata yang menyatakan perbuatan, tindakan yang dilakukan oleh seseorang dan biasanya jenis kata ini umunya menjadi predikat dalam suatu frase atau kalimat.

Bahasa Dayak Kanayatn adalah sebuah bahasa yang dipertuturkan di wilayah Kabupaten Landak, Kalimantan Barat, Indonesia. Khususnya di Dusun Simpang Tiga Desa Tapakng Kecamatan Sompak. Menurut Rufinus, dkk. (1997) "Bahasa Dayak Kanayatn merupakan bahasa utama yang dominan dalam berkomunikasi sehari-hari. Bahasa daerah ini digunakan hampir di segala aspek kegiatan: di pasar, di ladang, di rumah, di lingkungan sekolah (bukan dalam proses belajar mengajar)" (hlm. $10)$.
Menurut Maniamas, dkk. (2003) “Bahasa Dayak Kanayatn merupakan bahasa utama yang dominan dalam berkomunikasi sehari-hari" (hlm. 53). Sedangkan Menurut Alloy, dkk. (2008) Dayak Kanayatn Mampawah adalah salah satu Subsuku Dayak yang tersebar di sepanjang Sungai Mampawah. Sedangkan bahasa yang dituturkan oleh Suku Dayak Mampawah adalah bahasa Banana' atau Ba'ahe. Di kalangan khalayak ramai, bahasa ini disebut juga bahasa Kanayatn dan orang-orang yang menuturukan bahasa ini disebut orang Dayak Kanayatn (hlm. 159).

Penelitian tentang relasi makna kata sudah pernah dilakukan oleh mahasiswa IKIP PGRI Pontianak yaitu Herkulanus Setar (2015). Setar meneliti relasi makna kata dengan judul "Relasi Makna Kata dalam Bahasa Dayak Bekidoh Kecamatan Jangkang" setar dalam penelitiannya meneliti tentang relasi makna kata sinonim, kata antonim, kata homonim, kata hiponim, dan yang terakhir kata polisemi. Adapun hasil penelitan setar terdapat lima puluh satu pasang sinonim yaitu sinonim total dan komplit, sinonim tidak total tetapi komplit, sinonim total tetapi tidak komplit, dan sinonim tidak total dan tidak komplit. Terdapat empat puluh delapan pasang antonim yang terbagi menjadi lima jenis antonim yaitu antonim mutlak, antonim kutub, antonim hubungan, antonim hierarkial dan antonim majemuk, dua belas homonim, sepuluh hiponim, dan lima belas polisemi. 


\section{METODE PENELITIAN}

Metode yang digunakan dalam penelitian ini adalah metode deskriptif. Nawawi (2015) mengemukakan bahwa "Metode deskriptif dapat diartikan sebagai prosedur pemecahan masalah yang diselidiki dengan menggambarkan/melukiskan keadaan subjek/ objek penelitian (seseorang, lembaga, masyarakat, dan lain-lain) pada saat sekarang berdasarkan fakta-fakta yang tampak, atau sebagaimana adanya" (hlm. 67).

Bentuk yang digunakan dalam penelitian ini adalah bentuk penelitian kualitatif. Moleong (2017) "penelitian kualitatif adalah penelitian yang menghasilkan prosedur analisis yang tidak menggunakan prosedur analisis statistik atau cara kuantifikasi lainnya" (hlm. 6).

Data yang digunakan dalam penelitian ini adalah tuturan berupa kata-kata dan kalimat bahasa Dayak Kanayatn Kecamatan Sompak dialek Ahe Kabupaten Landak yang mengandung relasi makna verba antonim yang dituturkan oleh masyarakat penutur sesuai dengan fokus penelitian. Afifuddin (2009) "data pada penelitian kualitatif, data bersifat deskriptif. Maksudnya, data dapat berupa gejala-gejala yang dikategorikan ataupun dalam bentuk lainnya, seperti foto, dokumen, artefak, dan catatan-catatan lapangan pada saat penelitian dilakukan" (hlm. 96).

Sumber data yang digunakan dalam penelitian ini adalah masyarakat yang dipilih peneliti sebagai informan yaitu tiga orang masyarakat sebagai instrument kunci utama dan dibantu oleh warga/masyarakat di Dusun 155 |
Simpang Tiga Desa Tapakng Kecamatan Sompak, Kabupaten Landak yang menggunakan relasi makna verba dalam bahasa Dayak Kanayatn. Zuldafrial (2012) mengemukakan bahwa "sumber data dalam penelitian adalah subjek dari mana data dapat diperoleh" (hlm. 46). Teknik pengumpulan data yang digunakan peneliti dalam penelitian ini adalah: teknik simak libat cakap, teknik komunikasi langsung, dan teknik observasi, Adapun alat yang digunakan oleh peneliti adalah peneliti sendiri sebagai instrumen kunci serta alat bantu lainnya seperti: alat perekam suara, pedoman wawancara, dan pedoman observasi.

Teknik analisis data yang digunakan dalam penelitian ini adalah teknik analisis model interaktif. Prosedur analisis data dalam penelitian ini setelah pengumpulan data, dilakukan analisis awal bersama dengan pengamatan dan wawancara, selama pengumpulan data berlangsung proses analisis dilakukan yaitu dengan melakukan reduksi data, penyajian data dan penarikan kesimpulan.

\section{PEMBAHASAN}

Antonim merupakan hubungan semantik antara dua buah kata yang maknanya menyatakan pertentangan atau kebalikan. Atau lebih sederhananya antonim adalah suatu kata yang berlawana makna dengan kata lain.

\section{A. Antonim Mutlak dalam bahasa Dayak Kanayatn}

Antonim mutlak adalah dua buah kata yang berlawanan atau bertentangan secara 
mutlak. Dalam penelitian ini ditemukan beberapa antonim. Selanjutnya akan dijelaskan sebagai berikut.

\section{Data 1. Deak > galak}

Leksem yeak adalah suatu hal yang melahirkan perasaan sedih, kecewa, menyesal dengan mencucurkan air mata serta mengeluarkan suara. Leksem galak adalah sesuatu yang melahirkan rasa gembira, senang, geli dengan suara berderai. Dari penjelasan tersebut keduanya memiliki sifat yang tidak sama (berantonim). Leksem yeak $><$ galak termasuk ke dalam jenis antonim mutlak. Adapun kalimat yang ditemukan sebagai berikut.

Dora yeak baray dimutus'si ja cowokna. Dani gi galak nonton lawa'

'Dora menangis karena diputuskan sama pacarnya. Dani sedang tertawa menonton lawak'.

Pada kalimat di atas percakapan tersebut dilakukan oleh Lerong yang berbicara dengan Lasmini. Kalimat di atas mengandung perbedaan makna yang mutlak karena ngeak sudah jelas tidak galak.

\section{Data 2. Makah $><$ nocok}

Leksem makah merupakan suatu tindakan memasukan sesuatu ke dalam mulut dengan cara mengunyah atau menelannya. Leksem nocok adalah suatu tindakan memasukan air atau benda cair ke dalam mulut lalu meneguknya. Penjelasan tersebut menunjukkan keduanya memiliki sifat yang tidak sama (berantonim). Leksem makah >< 156 nocok termasuk ke dalam jenis antonim mutlak karena leksem makah menegaskan apabila sedang makah berarti tidak sedang nocok. Adapun kalimat yang ditemukan sebagai berikut.

Dah laka maka b barulah nocok ai Tasia $a^{\prime}$

'Setelah selesai makan barulah minum air Tasia'.

Pada kalimat di atas percakapan tersebut dilakukan oleh Ibu Usna yaitu ibu dari Tasia yang berbicara dengan Tasia di dapur. Berdasarkan kalimat di atas maka 5 dan nocok itu berbeda (berantonim), secara mutlak karena dari kedua leksem tersebut jelas menunjukan perbedaan.

\section{Data 3. Tidur $><$ lumpat}

Leksem tidur merupakan suatu hal dalam keadaan berhenti badan dan kesadarannya biasanya dengan memejamkan mata. Leksem lumpat adalah bangkit, berdiri dari duduk, tidur dan sebagainya. Dari penjelasan tersebut keduanya memiliki sifat yang tidak sama (berantonim). Leksem tidur $><$ lumpat termasuk ke dalam jenis antonim mutlak. Adapun kalimat yang ditemukan sebagai berikut.

Dani biasana kao tidur jam sayahe ke malam ari? Ja Satijo, aku si lumpat jam 06.00 tepat biasana.

'Dani biasanya kami tidur jam berapa kalau malam hari? Kata Satijo, saya biasanya bangun jam 06.00 tepat'.

Pada kalimat di atas percakapan tersebut dilakukan oleh Satijo yang berbicara dengan Dani di teras rumah. Percakapan tersebut didapat 
peneliti di Dusun Simpang Tiga Desa Tapakng pada hari sabtu, 27 April 2019 di Sore hari. Kalimat di atas mengandung perbedaan makna yang mutlak karena tidur sudah jelas tidak lumpat.

\section{B. Antonim Hubungan dalam bahasa Dayak}

\section{Kanayatn}

Antonim Hubungan adalah lawan kata yang beroposisi hubungan (relasional) ini bersifat saling melengkapi. Adanya kehadiran kata yang satu karena ada kata yang lain yang menjadi oposisinya. Tanpa kehadiran keduanya maka oposisi ini tidak ada.

\section{Data 1. nual $><$ mali}

Leksem nual adalah suatu tindakan memberikan sesuatu kepada orang lain untuk memperoleh uang pembayaran atau menerima uang. Leksem mali merupakan tindakan memperoleh sesuatu melalui penukaran (pembayaran) dengan uang, memperoleh atau memiliki sesuatu dengan membayar. Penjelasan tersebut menunjukkan keduanya memiliki sifat yang tidak sama (berantonim). Leksem nual $><$ mali termasuk ke dalam jenis antonim hubungan karena leksem jual dan mali menegaskan maknanya berlawanan tetapi proses terjadinya berlaku serempak. Proses nual dan proses mali terjadi pada waktu yang bersamaan, sehingga bisa dikatakan tidak akan ada proses nual jika tidak ada proses mali. Adapun kalimat yang ditemukan sebagai berikut.

Sayahe kita nual talok manok nia Wek 'berapa ibu menjual telur ayam ini Ibu Eni? Saya mau membelinya'.

Pada kalimat di atas percakapan tersebut dilakukan oleh Dewi yang berbicara dengan Ibu Eni di toko. Kalimat di atas mengandung perbedaan makna hubungan dan proses kejadiannya berlaku serempak.

\section{Data 2. Maju $><$ mundur}

Leksem maju adalah suatu kegiatan berjalan (bergerak) ke muka, tampil ke muka, melangkah ke depan. Leksem mundur merupakan suatu tindakan berjalan atau bergerak ke belakang. Penjelasan tersebut menunjukkan keduanya memiliki sifat yang berlawanan (berantonim). Leksem maju $>$ mundur termasuk ke dalam jenis antonim hubungan karena leksem maju dan mundur menegaskan maknanya berlawanan tetapi proses terjadinya berlaku serempak. Proses maju dan proses mundur terjadi pada waktu yang bersamaan, sehingga bisa dikatakan tidak akan ada proses maju jika tidak ada proses mundur. Perhatikan contoh kalimat berikut ini.

Dewa maju deh doho kao ka depan. Dah koa mundur ka belakaylah agi.

'Dewa maju duku kamu di depan. Sudah itu mundur di belakang lagi’.

Pada kalimat di atas percakapan tersebut dilakukan oleh Bapak Martinus yang berbicara dengan Dewa saat latihan baris berbaris di Sekolah. Berdasarkan kalimat di atas leksem maju dan mundur itu berlawanan (berantonim), Kalimat di atas mengandung perbedaan makna Eni? Aku mali ana. 
hubungan dan proses kejadiannya berlaku serempak.

\section{Data 3. Turu h $><$ naik}

Leksem turu 5 merupakan suatu kegiatan bergerak ke arah bawah, bergerak ke tempat yang lebih rendah dari pada tempat semula. Leksem naik adalah suatu kegiatan bergerak ke atas atau ke tempat yang lebih tinggi mendaki atau memanjat. Penjelasan tersebut menunjukkan keduanya memiliki sifat yang berlawanan (berantonim). Leksem turuh $><$ naik termasuk ke dalam jenis antonim hubungan karena leksem turutn dan naik menegaskan maknanya berlawanan tetapi proses terjadinya berlaku serempak. Proses turuЂ dan proses naik terjadi pada waktu yang bersamaan, sehingga bisa dikatakan tidak akan ada proses turu $\zeta$ jika tidak ada proses naik.

Perhatikan contoh kalimat berikut ini.

Doni tadi kao turuh ka oto ke? Mabukke? Aku si ke naik oto pasti ka kap biar nak mabuk.

'Doni tadi kamu turun dari mobil kah? Mabukkah? Saya kalu naik mobil pastu di atas biar tidak mabuk'.

Pada kalimat di atas percakapan tersebut dilakukan oleh Aris yang berbicara dengan Doni, di teras rumah Doni. Berdasarkan kalimat di atas leksem turuh dan naik itu berlawanan (berantonim), Kalimat di atas mengandung perbedaan makna hubungan dan proses kejadiannya berlaku serempak.

\section{Data 4. Pulaky $><$ ampus}

Leksem pulaky adalah suatu kegiatan pergi ke rumah atau ke tempat asalnya, kembali atau balik. Leksem ampus merupakan suatu tindakan berjalan atau bergerak maju meninggalkan suatu tempat. Penjelasan tersebut menunjukkan keduanya memiliki sifat yang berlawanan (berantonim). Leksem pulaky $><$ ampus termasuk ke dalam jenis antonim hubungan karena leksem pulakng dan ampus menegaskan maknanya berlawanan tetapi proses terjadinya berlaku serempak. Proses pulaky dan proses ampus terjadi pada waktu yang bersamaan, sehingga bisa dikatakan tidak akan ada proses pulaky jika tidak ada proses ampus. Perhatikan contoh kalimat berikut ini.

Gumare sidi kao pulakg ka rumah Ko? Nak Ke kao ampus moton alaph-alaph tadi?

'sore sekali kamu pulang ke rumah Riko?

Tidakkah kamu pergi noreh subuh-subuh tadi'

Pada kalimat di atas percakapan tersebut dilakukan oleh Wardi yang berbicara dengan Riko di ladang. Berdasarkan kalimat di atas leksem pulaky dan ampus itu berlawanan (berantonim), Kalimat di atas mengandung perbedaan makna hubungan dan proses kejadiannya berlaku serempak.

\section{Antonim Majemuk dalam bahasa Dayak Kanayatn}

Antonim majemuk merupakan antonim yang melibatkan banyak kata. Contohnya adalah kalimat rumah itu berwarna merah yang berlawanan dengan rumah itu berwarna hijau. 
Data 1. Badiri ><duduk, guriky, tidur

Leksem badiri merupakan sebuah perbuatan atau tindakan atau perbuatan yang tidak duduk atau berbaring, bertumpu tegak pada kaki. Leksem duduk merupakan tindakan meletakkan tubuh atau letak tubuhnya dengan bertumpu pada pantat. Leksem badiri $><d u d u k$, guriky , tidur termasuk ke dalam jenis antonim majemuk karena memiliki pasangan antonim yang lebih dari satu. Apabila dikatakan berdiri berarti tidak $d u d u k$, tidak guriky, dan tidak juga tidur. Perhatikan contoh kalimat berikut ini.

Dani gahe kao badiri ka depan pintu, coba duduk kean.

'Dani kenapa kamu berdiri di depan pintu, coba duduk dini'.

Pada kalimat di atas percakapan tersebut dilakukan oleh Pak Alinus yang berbicara dengan Dani di rumah. Makna kata badiri pada contoh kalimat di atas menyatakan bahwa orang tersebut sedang tidak $d u d u k$, tidak guriky, dan tidak juga tidur.

\section{PENUTUP}

Antonim Verba dalam Bahasa Dayak Kanayatn memiliki tiga bentuk antonim yaitu: (a) antonim mutlak seperti: kata neak (menangis) dengan kata galak (tertawa). kata makatn (makan) dengan kata nocok (minum). kata tidur (tidur) dengan kata lumpat (bangun). (b) Antonim majemuk seperti: antonim hubungan seperti: kata nual (menjual) dengan kata mali (membeli). kata maju (maju) dengan kata mundur (mundur). kata turutn (turun) dengan kata naik (naik). kata pulaky (pulang) dengan kata ampus (pergi). antonim majemuk seperti: kata badiri (berdiri) dengan kata duduk (duduk) dan gurikg (berbaring), tidur (tidur).

\section{DAFTAR PUSTAKA}

Afifuddin, H. \& Saebani, B.A. (2009). Metodologi Penelitian Kualitatif. Bandung: CV Pustaka Setia.

Alwasilah, C. (2011). Linguistik Suatu Pengantar. Bandung: Angkasa.

Aminuddin. (2011). Semantik Pengantar Studi Tentang Makna. Bandung: Sinar Baru Algensindo.

Anwar, D. (2003). Kamus Lengkap Bahasa Indonesia Terbaru Dilengkapi Pedoman Umum Ejaan Bahasa Indonesia yang Disempurnakan. Surabaya: Amelia.

Chaer, A. (2009). Pengantar Semantik Bahasa Indonesia. Jakarta: Rineka Cipta.

Djajasudarma, F. (1999). Semantik 1 Pengantar Ke Arah Ilmu Makna. Bandung: PT Refika.

Finoza, L. (2009). Komposisi Bahasa Indonesia Untuk Mahasiswa Nonjurusan Bahasa. Jakarta: Diksi Insan Mulia

Tarigan, H.G. (2011). Pengajaran Kosakata. Bandung: Angkasa.

Karim, Y. dkk.. (2013). Semantik Bahasa Indonesia Teori dan Latihan. Tangerang: Pustaka Mandiri.

Maniamas, M. dkk. (2003). Tradisi Lisan Dayak yang Tergusur dan Terlupakan. Pontianak: Institut Dayakologi.

Melia \& Ramaniyar, E. (2016). Analisis Verba Bahasa Melayu Dialek Pontianak. Jurnal Pendidikan Bahasa, 5 (1), 63.

Mulae. S.O. (2015). Pengantar Morfologi Bahasa Etnik Kao dan Bahasa Melayu Ternate. Yogyakarta: Morfalingua.

Moleong, L.J. (2017). Metodologi Penelitian Kualitatif Edisi Revisi. Bandung: PT Remaja Rosdakarya Offset.

Nawawi, H. (2015). Metode Penelitian Bidang Sosial. Yogyakarta: Gadjah Mada University Press.

Oktaviani, N. dkk.. (2009) Sinonim, Repetisi dan Antonim dalam Bahasa Jepang: Telaah 
Majalah Nihongo Journal dan Hiragana Times. Jurnal Lingua Cultur, 3 (1), 39.

Rohmadi, M. \& Wijana, D.P. (2011). Semantik Teori dan Analisis. Surakarta: Yuma Pustaka.

Rufinus, A. (1997). Mencermati Dayak Kanayatn. Pontianak: Institute of Dayakology Research and Development.

Solahudin, M. (2009). Pedoman Menaklukkan Parts Of Speech. Jogjakarta: DIVA Press.
Tarigan, H.G. (2009). Pengajaran Semantik. Bandung: Angkasa.

Wijana, D. P. (2015). Pengantar Semantik Bahasa Indonesia. Yogyakarta: Program Studi S2 Linguistik Fakultas Ilmu Budaya Universitas Gadjah Mada.

Wahyudi, A.B. dkk. (2012). Morfologi Telaah Morfem dan Kata. Surakarta: Yuma Pustaka.

Zuldafrial. (2012). Penelitian Kualitatif. Pontianak: STAIN Pontianak Press 